\title{
Rapeseed meal detoxification in moist maize silage : utilization of this feed in growing pigs
}

\author{
L. P. BORGIDA ( ${ }^{(3)}$, J. DELORT-LAVAL, (1), D. BOURDON ( $\left.{ }^{2}\right)$ et G. VIROBEN (1) \\ (1) I.N.R.A. Laboratoive de Technologie des Aliments des Animaux, 47072 Nantes (France) \\ ${ }^{2}$ ) I.N.R.A. Station de Recherches suv l'Elevage des Porcs, 78350 Jouy-en-Josas (France)
}

( $\left.{ }^{3}\right)$ Ucanor, 14650 Carpiquet (France)

The effect of incorporating rapeseed or soyabean oil-meal into moist maize silage (6o \% D.M.) in the proportion of 27 and 23 per cent, respectively was studied from a biochemical and nutritional point of view.

- silage fermentation only slightly affected meal protein degradation, but the lactic fermentation increased as compared with maize silage alone;

- as compared to dry feed of the same composition, silage gave higher growth rates in castrates or female Large White pigs restricted between 25 and roo $\mathrm{kg}$ live weight;

- the detoxification of rapeseed meal, evidenced by a much lower thyroid weight in the castrates, resulted in the same growth rates during the finishing period as those obtained with soyabean, but the carcasses of the animals fed with rapeseed were leaner.

\section{Protein sparing effect of a growth promotant (Carbadox) used in growing pigs}

\author{
D. BOURDON ('). J. P. RAYNAUD (2) et R. FERRANDO ( $\left.{ }^{3}\right)$ \\ (1) Station de Recherches sur l'Elevage des Porcs, \\ I.N.R.A.-C.N.R.Z., 7835o Jouy-cn-Josas (France) \\ (2) Station de Recherches et Développement vétérinaive et Nutrition aninale, \\ Pfizer Intemational, 37400 Amboise (France) \\ (3) Ecole nationale vétérinaire, Laboratoire de Nutrition et d'Alimentation, \\ 7, avenue du Général-de-Gaulle, 947or Maisons-Alfort (France)
}

Three successive experiments were conducted in the same piggery according to the same design using an "optimum" and a "sub-optimum" protein diet. The pigs were divided into 2 groups, the one did not receive any supplement (controls) and the other was offered $50 \mathrm{ppm}$ carbadox until $35 \mathrm{~kg}$ live weight, $25 \mathrm{ppm}$ until $70 \mathrm{~kg}$ liveweight and then no supplement. The "sub-optimum" diet was qualitatively and quantitatively protein deficient.

The pigs were fed ad libitum from $15-20$ to $100 \mathrm{~kg}$ live weight. As compared with the controls, utilization of 50 ppm carbadox up to $35 \mathrm{~kg}$ live weight led to a highly significant increase of growth performance and a significantly improvement of feed conversion ratio and protein efficiency. The analyses made at roo $\mathrm{kg}$ showed that the improvement obtained with carbadox was similar for the two types of diets. The fattening length was reduced by 9 days (due to a higher daily mean gain), the feed intake decreased by $4 \mathrm{~kg}$ and the consumption of crude protein by $600 \mathrm{~g}$. Utilization of carbadox resulted in a financial gain of $7 \mathrm{~F}$ for the pigs fed with the "sub-optimum" diet and of ro F for "those receiving the "optimum" diet. Consequently, this growth promotant allows to improve biological feed efficiency and management economy. 